\title{
The Influence of Greek Spirituality on Russian Culture
}

\author{
Ján Zozul'ak
}

check for

updates

Citation: Zozul'ak, Ján. 2021. The Influence of Greek Spirituality on Russian Culture. Religions 12: 455. https://doi.org/10.3390/rel12070455

Academic Editors: Michal Valčo, Jove Jim S. Aguas and Kamil Kardis

Received: 11 May 2021

Accepted: 18 June 2021

Published: 22 June 2021

Publisher's Note: MDPI stays neutral with regard to jurisdictional claims in published maps and institutional affiliations.

Copyright: (C) 2021 by the author. Licensee MDPI, Basel, Switzerland. This article is an open access article distributed under the terms and conditions of the Creative Commons Attribution (CC BY) license (https:/ / creativecommons.org/licenses/by/ $4.0 /)$.
Faculty of Arts, Constantine the Philosopher University in Nitra, 94974 Nitra, Slovakia; jzozulak@ukf.sk

\begin{abstract}
In this article, we will analyze the influence of Greek spirituality on Russian culture in the second half of the 18th century, when Enlightenment ideas infused Russian society. Russian intellectual circles and the upper social class were inspired by Western categories of thought. The absence of a living theology that would give man the true meaning of life has caused tension and a great spiritual crisis in Russian society. One possible solution was to start a fight against the Enlightenment and reject any Western ideas. The second solution was to pay attention to the forgotten tradition and look for inspiration in it for the renewal of spiritual life. The spiritual renewal, known as the philokalic movement, leaned towards the second solution, building upon the Byzantine hesychastic tradition of the 14th century. This paved the way for a new era of Orthodox spirituality, which significantly influenced thinking and spiritual life in Russia. The movement of spiritual renewal is associated with the translation and publication of manuscripts written by Byzantine niptic authors, which were published in the book Dobrotolublye (gr. Philokalia). This significantly contributed to the spread of the hesychastic tradition in Russia and became an impetus for a return to Byzantine spiritual values. This article examines the spiritual, literary, and cultural activities of the most important centers of Russian Hesychasm, such as Sarov, Valaam, and Optina, and their influence on Russian society, which has not yet been recognized sufficiently.
\end{abstract}

Keywords: Greek spirituality; Russian culture; philokalic movement; hesychastic tradition; Philokalia; enlightenment; niptic texts

\section{Introduction}

Prior to analyzing the influence of Greek spirituality on Russian culture, an outline of relations between Russia and the Holy Mountain Athos, which go back as far as the 10th century, needs to be provided. The first testimony of a Russian monastery at Athos, the hegumen of which was Gerasim, dates to the year 1016 (Lemerle 1970). On the basis of historical information about the life of the Russian monk Anthony of Kiev, who lived for a time at the Holy Mountain as a hermit in the 11th century, it can be concluded that Russian monks gravitated towards an eremitic way of monastic life, as opposed to cenobitic. Some researchers dispute Anthony's stay at Athos, claiming that he lived in Bulgaria, on the grounds that he did not speak Greek, without providing more substantial arguments (Priselkov 1913, pp. 168-69), not taking into account that he had most likely become a monk in the aforementioned Russian monastery (Thomson 1995, pp. 637-68; Uspenskij 2016, pp. 70-113).

Despite historical sources not providing clear testimonies of Anthony's stay at Athos, we subscribe to the view that he did, in fact, visit the Holy Mountain Athos and lived there as a hermit for a time. It is not known what typikon ${ }^{1}$ was in force in the oldest Russian monastery on the Holy Mountain Athos, where Anthony lived; however, on the basis of the fact that, after his return to Russia, he preferred eremitic monastic life to cenobitic, it can be assumed that he had not come into contact with the monastic typikon of Athanasius the Athonite of the Great Lavra, thus not introducing it to Russia on his return. Later, he gave his blessing to the monk Theodosius' becoming the hegumen of the Kyiv Pechersk Lavra (Киево-Печерская Лавра [Kyievo-Pecherska Lavra]) ${ }^{2}$, who employed the typikon of the 
Studite monastery in Constantinople in this first Russian cenobitic monastery, established in 1051 (Tachiaos 2006, p. 452; Poppe 2011).

Despite the fact that the typikon of the Holy Mountain Athos was not introduced in Russia, in Kievan Cave Paterikon (Olshevskaya and Travnikov 1999), it is repeatedly emphasized that Anthony of Kiev brought the Holy Mountain's blessing to Russia. On the basis of this information, it can be assumed that the reverence of the Athos monasticism became an impulse for the departure of many monks from Russia to the Holy Mountain. The ties between Russia and Athos strengthened, resulting in the Greek spirituality being transposed into the Russian cultural context.

It is also necessary to take into account the fact that the Studite typikon was established by the Metropolitan of Kiev and all Rus' George (ca. 1065-ca. 1076), a Greek, who-as a former member of the Senate of the Byzantine capital—certainly considered the typikon of the ancient monastery in the center of the world at that time to be the more authentic. Additionally, Russia wanted to maintain ties to Constantinople (Tachiaos 2006, p. 456).

The monasteries on the Holy Mountain Athos gradually became the centers of spiritual and cultural life, with their influence spreading beyond the borders of Athos itself. Monastic libraries quickly began to fill with liturgical, theological, historical, and other manuscripts. Transcription and translation workshops were set up in the Athonite monasteries, where translations into various languages were produced. It was the Slavic monasteries that gradually became the centers of Slavic translation activities (Tachiaos 1978, pp. 1-35), thus having a great influence on Slavic countries. Based on the surviving testimonies, it is possible to follow the translation activities of Bulgarian and Serbian monks, who worked with Greek source texts. For example, a critical edition of 95 Athonite Slavic manuscripts dating from 1230 to 1734 consists of 39 documents in Bulgarian or Serbian and 56 documents of Moldovan or Vlachian origin written in Bulgarian strongly influenced by Romanian syntax and terminology used in the two Transdanubian principalities. The Serbian and Bulgarian documents contained in this edition are kept in the archives of the Karakallou, Konstamonitou, St. Paul, Vatopedi and Xenofontos monasteries (Pavlikianov 2018).

In this paper, we will deal with the spiritual crisis of Russian society that occurred within the context of Enlightenment, and with its search for a solution to this crisis. We will focus on the translation and publishing of Greek niptic manuscripts, their influence on spiritual life and the spread of the Greek hesychastic tradition in Russia through the influential spiritual centers of Sarov, Valaam and Optina, to where the Greek philokalic spirit was transposed. We will introduce the publishing activities of Macarius of Optina and clarify the importance of the issuing of Philokalia-Dobrotolublye in the Russian language, which had a major impact on Russian spirituality and culture.

\section{Enlightenment and Spiritual Crisis in Russian Society}

Up until the 15th century, the Byzantine Empire was a great source of ideas for Russian thinkers. They lost this source in 1453 . Since that point, Russia had to rely on its own spiritual and cultural resources and venture its own way. Here, a problem arose: Russian intelligence was not able to satisfy the deeper spiritual needs of an educated public. Russian intellectuals turned westward in their search for models. Thus started the process of the adoption of Western thought by Russian society, culminating at the beginning of the 18th century, during reforms of Peter the Great (1682-1725), and continuing through the educational policies of Catherine II (1762-1796) (Zenkovskij 1948, pp. 82-110). This reform led to a new spiritual and social climate, as education in Russia was remodeled after Western patterns and when Enlightenment movements started appearing in the country, they permeated into society surreptitiously. Additionally, Russian intellectuals and high society were inspired by the Western categories of thought and logic.

The influence of Enlightenment on Russia resulted in a spiritual crisis, which left a deep mark on the entire society. The fear of expansion of Enlightenment ideas quickly became a cause for panic, as Russian Orthodox believers, who were essentially required to believe on request or dictate of the Church authorities for centuries, were suddenly 
confronted with ideas challenging their faith and subjecting it to criticism in the name of human ratio, which was nearly deified and disregarded the previous authority of the Church (Tachiaos 2006, p. 219). The ecclesiastical hierarchy was troubled by the new situation and, instead of a constructive method of persuasion, it utilized an unadvised method of prohibition (Gedeon 1976, pp. 97-113). The result of such an approach was an absolute rejection of any idea of Western origin, leading many intellectuals studying Western science to distance themselves from the Church. In these complex times, clergy were not able to adequately react to the new Enlightenment ideas and present the riches of orthodox Byzantine theology, but limited themselves to the defense of the Christian faith by regulations and instructions that could not satisfy the needs of intellectuals, who had already been strongly influenced by Western movements. On one hand, there were the progressive intellectuals, mesmerized by Western thought and oscillated between scholastic theology and Enlightenment. On the other hand, there were conservative monks, who paid more attention to the traditions themselves than to actual spiritual life. They were content with practical life and liturgic formalism, as they did not know the works describing niptic life and the way of spiritual self-improvement.

The spread of Enlightenment ideas and the absence of living theology that would offer real meaning of life and satisfy the needs caused a great spiritual crisis in Russian society and, for many educated people, this became a reason for departure from the Church. Understandably, there formed a need to find the right recourse from this situation. One of the possible solutions was starting a fight against Enlightenment and refusing any and all Western ideas. The second possibility was to turn attention to the forgotten tradition and thus search for inspiration for a possible renewal of spiritual life. A spiritual renewal known as the philokalic movement leaned towards the second solution and built on the hesychastic tradition of the 14th century, the essence of which lied in the focus on constant prayer of the mind, through which man can become one with God. The philokalic movement, which formed almost simultaneously in Greek (Karamanidou 2016, pp. 167-69) and Slavic contexts in the latter half of the 18th century, became an impulse for a rediscovery of hesychastic tradition and a return to spiritual values of the Byzantine era. A discussion started regarding the position of humanity in the world and in history, one different from what Enlightenment claimed.

\section{Translation and Publishing of Greek Manuscripts of Niptic Authors}

Spiritual renewal in Russia is linked to the activities of Paisius Velichkovsky (1722-1794), who abandoned his studies at the Kiev Theological Academy, because he could not come to terms with the opinions of his tutors, who presented the theses of ancient philosophers as equal to Christian virtues. In his autobiography, Paisius later describes his defense before the rector, in which he explains his reasons for leaving the Theological Academy (Tachiaos 1986, pp. 17-19), specifying that he also could not subscribe to the ideals of Enlightenment, which claimed that human ratio must be able to function freely and independently on any theological understanding. He was much more enticed by the thoughts of Greek niptic thinkers, who analyzed the issues related to the purification of the human mind and knowledge of God.

Paisius then lived in monasteries in Ukraine and Vlachia for several years, but did not find what he was looking for. He left for the Holy Mountain in 1746, with an idealistic vision about Athonite monasticism, but did not encounter the desired level of spirituality even there. Everywhere he met conservative monks, who focused predominantly on tradition, not on truly spiritual life. His experience with Athonite monks, who did not know niptic ascetic texts of the Byzantine thinkers, is described in a letter to monk Theodosius (Zhitiye 1847, p. 213), in which Paisius mentions that he was greatly surprised to learn that the monks did not even know the names of niptic authors when asked about them. They were content with practical life and liturgic formalism.

Paisius met simple ascetics, who dealt with transcribing Byzantine niptic texts. He came into contact with them and became familiar with many ascetic writings 
(Tachiaos 1964, p. 41), which he attained interest in and started studying. His philological activity started with him ordering to have selected Byzantine texts rewritten for him by these ascetics. The studying of these works opened new spiritual vistas for Paisius-the ones he was searching for in vain until that moment. Paisius himself became a starets ${ }^{3}$ and significantly contributed to the Russian spiritual renewal. In this, he was assisted by the aforementioned niptic texts, as he found in them a new dimension of spiritual life, hitherto unknown to him, yet one he has already observed in Vlachia, when he met starets Basil, the hegumen of Poiana Mărului Skete, who was one of the first neo-Hesychast writers of the 18th century. Father Basil later visited Paisius at the Holy Mountain Athos and encouraged him in his translational work. From Paisius' autobiography, it is clear that starets Basil was a great spiritual leader, however, only very little is known about his life and theological activities (Joanta 1987, pp. 143-59).

Paisius Velichkovsky lived at Athos for eighteen years. When he decided to translate Byzantine niptic ascetic texts from Greek into Slavic language, he amassed a group of coworkers, who cooperated on the translations or transcribed the ones he made himself. The important factor in his work was his frequent application of the critical method of text study, which was almost unheard of at that time in the Christian East (Tachiaos 1964, pp. 55-71). Over several years, Paisius and his colleagues worked on producing a rich translation library of ascetic books. After leaving Athos and returning to Moldova in 1764, he expanded this library by additional manuscripts, so that it could serve the constantly increasing number of monks coming to visit him in the monastery. At the same time, Paisius also closely observed the activities of Macarius Notaras (1731-1805), the founder of the philokalic movement (Papadopoulos 2000, p. 45), who was collecting the texts of Byzantine niptic authors in the libraries of Patmos, Chios, and Athos (Zacharopoulos 1984, pp. 92-93). Together with Nicodemus of the Holy Mountain (1749-1809), they endeavored to publish the Greek Philokalia in Venice in 1782. This volume contained thirty-six ascetic and niptic works (Tachiaos 1964, pp. 108-19).

The publishing of this voluminous collection of experiences of niptic authors was a remarkable event for Greek intellectual circles, who were in this way provided with a rich source of inspirational ideas. Macarius named it with the Greek word philokalia $(\varphi \iota \lambda \circ \kappa \alpha \lambda i \alpha)$, which means the sense for beauty, but also love of good, that is, something morally or emotionally beautiful. Philokalia is linked to love of God, who is the source of goodness. Etymological analysis of this word leads to its initial meaning $\kappa \alpha \lambda \alpha \iota \sigma \theta \eta \sigma i \alpha$, meaning aesthetics, taste. The word philokalia as an anthology of works was used to denote the cream of the crop. The same title was used by Gregory of Nazianzus (Theologian) in 361 to the anthology of texts by Origen, one of the greatest Christian thinkers, which he compiled together with Basil the Great. It can be assumed that the Philokalia compiled by Macarius Notaras and Nicodemus of the Holy Mountain was given this title under the influence of the Philokalia of Gregory of Nazianzus and Basil the Great (Krikonis 2001, p. 76).

Similar to Macarius Notaras, Paisius Velichkovsky was acutely aware of the fact that the spiritual crisis and emptiness in society was caused by the monks' distancing from the spirit of early fathers, which reaches as far back as to the times of Anthony the Great and Pachomius in the 4th century. He therefore decided to provide Slavs with the great wealth of thought and experience of niptic ascetic writers. He thus restored the forgotten Byzantine tradition in Slavic monasticism and transposed the spirit of Philokalism into Russian context. He translated the Greek niptic manuscripts dealing with spiritual issues into Church Slavonic, which were given the title Dobrotolublye and exactly matched the Greek meaning of the word philokalia. When he departed for Moldova, he left his disciple Gregory behind at Athos to join Macarius and help him transcribing manuscripts. He also informed Paisius about the activities and provided him with texts with niptic content.

By revival of forgotten niptic tradition, Paisius significantly contributed to the spiritual renewal of the 18th century, creating prerequisites for understanding the true meaning of human life. By making the ascetic works of Byzantine niptic authors available to Russian society, a strong influence of Greek spirituality on Russian culture began and the road was 
paved for a new era of Orthodox spirituality, which significantly influenced the thought and spiritual life not only in Russia, but also in Western Europe (Deseille 1997). E. Kadlubovsky and G. E. H. Palmer published English versions of the two volumes of Philokalia, which they compiled by selecting certain texts from the Russian translation. Similarly, J. Gouillard published a selection of texts dealing with constant prayer in French, under the title Petite Philocalie de la Priere du coeur, translated from Greek. Through this anthology, ascetic orthodox tradition came to be known in the Western world (Kitromilides 2000, pp. 34160 ), which caused a heightened interest of western intellectuals in orthodox spiritual life. Despite niptic authors of Philokalia addressing their works primarily to monks, their advice is useful for anyone looking for a way to spiritual perfection. These experienced ascetics became important guides in the spiritual lives of monks and laypeople alike throughout centuries, strengthening the morale of Christians by their teachings, positively influencing the entire society.

\section{Spiritual Life in Greek Hesychastic Tradition}

Publishing of the Greek manuscripts meant not only the salvation of old Byzantine texts at risk of destruction, but also making accessible the then-unknown thought of Byzantine niptic authors, pertaining to the issues of healing of mind through three stages of spiritual life: purification ( $\kappa \dot{\alpha} \theta \alpha \rho \sigma \iota \varsigma)$ of heart, illumination ( $\varphi \omega \tau \iota \sigma \mu o ́ \zeta)$ of mind and deification $(\theta \varepsilon \dot{\varepsilon} \omega \sigma \iota \zeta)$. These three stages were known already to Neoplatonists as purification ( $\kappa \alpha \dot{\theta} \alpha \rho \sigma \iota \zeta)$, illumination ( $\varphi \omega \tau \iota \sigma \mu o ́ \zeta)$ and perfection $(\tau \varepsilon \lambda \varepsilon i \omega \sigma \iota \zeta)$, however, Byzantine authors reworked their understanding within the framework of the difference between uncreated $(\ddot{\alpha} \kappa \tau \iota \sigma \tau \rho \zeta)$ and created $(\kappa \tau \iota \sigma \tau \sigma o \zeta)$ reality.

Byzantine niptic authors, whose thought is collected in Philokalia-Dobrotolublye, deal less with the questions of faith and focus more on the issues surrounding the ascetic struggle, constant prayer of the mind ( considered theoptia $(\theta \varepsilon 0 \pi \tau i \alpha)$ - unification of man with God by means of cultivating virtues through asceticism and spiritual watchfulness $\left(\nu \tilde{\eta} \psi \iota_{\zeta}\right)$ - to be the ideal of life. This

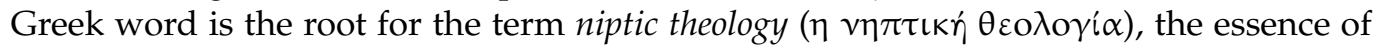
which is the constant prayer of Hesychasts-ascetics living in an uninterrupted connection to God via prayer, most frequently in remote eremitic locations. Authors of niptic texts developed not a scholastic theology, but a theology of prayer-niptic theology, that is why the efforts to achieve human perfection through spiritual struggle is the fundamental characteristic of Byzantine hesychastic tradition (Zozul'aková 2016, pp. 150-52). Through this ascetic struggle, man becomes purified from passions and becomes like God; for this reason, niptic ascetic literature places great emphasis on attaining virtues that lead man to perfection and unity with God.

In accordance with the Byzantine hesychastic tradition, niptic authors tried to obtain knowledge of Divine through participation $(\mu \varepsilon \varepsilon \varepsilon \xi \xi \varsigma)$ in Divine enlightenment. They followed the thought that the Divine substance is unattainable and unknowable for man, but man, in deification $(\theta \varepsilon \dot{\varepsilon} \omega \sigma \iota \zeta)$ - the final goal and meaning of life-comes into real participation in God through Divine energies, which are uncreated, but differ from substance (Župina 2017, pp. 79-80). Hesychasts try to see God through prayer and asceticism, thus using theology as a means for moving towards uncreated God. Anti-Hesychasts believed, on the basis of the rationalistic approach (Milko 2016, pp. 125-26), that knowledge of God is possible on the basis of abilities of the human mind and therefore considered theology an object of study.

It is predictable that the differences in backgrounds of Enlightenment and Hesychasm led to a controversy, similarly as in the 14th century, when a similar clash took place between Byzantine hesychastic and Latin scholastic theologies (Papadopoulos 1970, p. 46). Anti-Hesychasts based their thought on anthropological assumptions of Western thinkers; they over-emphasized human intellect and used Aristotelianism as basis of their ideas. Hesychasts (Lamprou 2017, p. 127), conversely, stressed the possibility of perceiving uncreated energies as the Divine light (the Tabor Light) and explained the process of human 
participation in uncreated Divine energies by means of constant prayer and purging of passions. They structured their thought on the grounds of Byzantine anthropology, the goal of which was the salvation of man and unification with God through vision $(\theta \varepsilon \omega \rho i \alpha)$ of Divine glory.

Collected and published texts of niptic authors belong among the influential written artefacts of the Byzantine era and are considered a fundamental guide to the human spiritual life, as they describe the method of healing of the soul and point to practical methods and ways of attaining purification of the soul of passions. Their deeper meaning lies in the fact that they help people attain the purity of heart ( $k \alpha \theta \alpha \rho \delta$ ó $\tau \alpha \kappa \alpha \rho \delta i \alpha \zeta)$, the watchfulness of mind ( $v \tilde{\eta} \psi \iota \varsigma$ voó $)$ ) and attaining grace ( $\chi \alpha \dot{\alpha} \rho \iota \zeta)$ of the Holy Spirit, leading man to the highest goal—deification $(\theta \varepsilon \dot{\varepsilon} \omega \sigma \iota \zeta)$.

Philokalia contains the spiritual experience of select fathers and represents a part of the immeasurable wealth of patristic literature. Despite it being an anthology of selected texts, it represents a complex of ascetic and hesychastic experience, showing the unity of main traits on one hand, and, on the other, making felt the peculiarities reflecting the uniqueness of each author. The apparent difference between the individual opinions on the same topic is caused by the difference of characters, degree of education, as well as a number of spiritual gifts of the niptic fathers, which testifies to a free presentation of their own spiritual experiences, which reveals the activity of the Holy Spirit in the pure souls of ascetics, who, through a persistent struggle, attain spiritual perfection and holiness.

\section{The Spread of Greek Hesychastic Tradition in Russia}

Sarov, Valaam, and Optina are among the most prominent centers of hesychastic tradition in Russia. These are the places where the disciples of Paisius Velichkovsky brought the translations of niptic texts and, with them, the philokalic spirit. The dominance of their influence can be perceived in three different dimensions: spiritual, literary, and cultural. The spiritual dimension of their influence is related to the niptic way of life and the spread of Greek hesychastic tradition in Russia. The literary dimension manifests through the publishing of Dobrotolublye and other niptic texts. The cultural dimension consists of the cooperation of a number of great startsy and Russian intellectuals. By analyzing these three dimensions, we will observe the influence of Greek spirituality on Russian culture on the turn of the 18th and 19th centuries.

The most prominent among figures of the Sarov hermitage was Seraphim of Sarov (1759-1833), who left a deep mark on Russian monasticism. Wishing to become a monk, he sought out the starets Dositheus, who was in touch with Paisius Velichkovsky and his disciples (Koncevitch 1981, p. 6). Starets Dositheus advised him to go to Sarov hermitage, where he devoted himself fully to the hesychastic way of life and constant prayer of the mind. He regularly studied Dobrotolublye and other niptic texts, seeking the answers to the questions of meaning of life and human purpose. Arduous spiritual struggle in the monastery and a great effort to purify his soul of passions elevated the venerable Seraphim to a high level of spiritual perfection and his soul burned with desire for hermetic life. In 1794 , he left for a hermitage, where he lived ascetically in a wooden cell in a hard-to-reach pine wood on the banks of the river Sarovka. These heavily thicketed hills dotted with cells of Sarovian hermits were not unlike the Holy Mountain Athos; for this reason, Seraphim called his new home a holy mountain.

In the years 1810-1825, the venerable Seraphim lived as a Hesychast and subsequently accepted the role of starets, i.e., a spiritual father, and, due to his love of his kin, started accepting visitors to his cell. At first, these were monks, whom he instructed to zealously observe monastic rules and train in constant prayer. Later, laypeople started seeking him out-to these, he gave short lectures. This Sarovian ascetic with perfect self-denial, patience, humility, and steadfast faith saw the greatest importance in the transformation of an old person into new, purification from passions and attainment of virtues leading to the human soul to be filled with inner peace that would bring the true joy of life. He regarded every person with deep respect and immense love. His calm manner of speech, filled with 
fatherly tenderness, warmed even the coldest of hearts, is reported to be able to bring tears of repentance and remorse, lead to the remedy of even the most callous of sinners and fill them with Divine peace.

Each day, more than two thousand people waited in front of his cell to talk with this charismatic starets. Everybody who visited the venerable Seraphim, be he poor or rich, was met with love, prostration, blessing, and a kiss. He is reported to never dole out harsh epitimia (punishment) nor burden, despite he himself bearing Christ's cross and enduring tribulations. He sometimes reproved people benevolently, but even then uttered each word with deep humility and kindness. He roused the conscience in people and changed their behavior with his teachings. Rich and poor, educated and uneducated, aristocrats and simple folk alike took away precious lessons from their meetings with him. Members of the royal family, senior government officials, and many people of prestige also paid visits to Seraphim of Sarov. In 1825, he was sought out by the Russian emperor Alexander I., who was likely complicit in the murder of his father Paul I., and, after a lengthy discussion, he went to the Sea of Azov, where he lived as a hermit (Timotheos 1991, p. 113).

Seraphim of Sarov applied the main niptic principles in his ascetic life, and, through spiritual advice to people that visited him, spread hesychastic tradition throughout Russia. He advised them to study Dobrotolublye and to apply the ideas of these texts, which have an immense impact on the lives of Christians. The practical importance of Dobrotolublye and focus on constant prayer of the mind are described exquisitely in the book Candid Narratives of a Pilgrim to His Spiritual Father, available in English under the title The Way of a Pilgrim, which became immensely popular in Russia at its release.

\subsection{The Publishing of Dobrotolublye}

Another important figure of Russian monasticism with a major impact on Russian spirituality and culture was Nazariy Kondratyev (1735-1809), who started his monastic life in Sarov hermitage, but moved to Valaam monastery to reconstruct it and introduce Sarovian typikon there at the behest of the Metropolitan of Novgorod and St. Petersburg, Gabriel. In January 1782, father Nazariy arrived at the abandoned and crumbling monastery on an island on Lake Ladoga, where he was made hegumen on 7 March 1782. By introducing the Sarov hermitage typikon, he established three different ways of monastic life in Valaam: cenobitic, sketic and eremitic. He recorded his monastic and pastoral wisdom in the book Teachings of Startsy (Старческое наставление [Starcheskoe nastavlenie]), in which he minutely describes the principles and rules of monastic life, providing many quotations from the Holy Scripture and works of niptic authors.

Many people sought out Nazariy's advice and wisdom. Word of the virtuous ascetic life of Valaam's monks under the leadership of hegumen Nazariy spread fast and attracted many others to the island (Minin 2011). In 1790, the monastery's brotherhood comprised twelve monks, in 1796, this number increased to fifty-five. The monastery experienced even greater growth in the middle of the 19th century.

Starets Nazariy was well aware that, to provide an authentic monastic life, it is not enough to rebuild the physical edifices of the monastery, rather, it is necessary to lead the monks spiritually and provide them with the teachings of ancient ascetics. He therefore proposed a translation of a collection of niptic texts Philokalia from Greek to Russian to be published. He wrote a letter to Paisius Velichkovsky outlining this intent and asked him to provide his hand-written translations for publishing. Starets Paisius agreed to publish Dobrotolublye in Russia (Tachiaos 2006, p. 226).

Issuing of the collection was supported by the Metropolitan of Novgorod and St. Petersburg, Gabriel, who participated in making the Byzantine niptic texts available to the Russian public. He rushed the publishing of Dobrotolublye in order to avoid negative reactions of the Russian Church hierarchy, which was not accepting of Byzantine hesychastic tradition, seeing in it a danger for Christian faith. At the same time, however, he was well aware that through these translations, new terms with subtle nuances will enter the Russian terminology, he therefore insisted on the translations being reviewed by two 
cooperating, independent groups of experts. The first comprised four monks, three of whom were coworkers of Paisius Velichkovsky, the second was made of professors of the Greek language of the St. Petersburg and Moscow theological academies.

In 1792, Valaam's hegumen Nazariy turned to the Holy Synod of the Russian Orthodox Church with a request for permission of publishing the collection Dobrotolublye at his own expense. Starets Nazariy paid for the translation of the Greek niptic texts and financially secured their printing at the Synod's printing press in Moscow, where, on 11 May 1793, a year before the death of Paisius Velichkovsky and eleven years after the issuing of Greek Philokalia, the first Russian edition of Dobrotolublye was printed, with a print run of 2400 copies. The first edition of the Russian collection contained twenty-four ascetic and niptic works.

The publishing of Dobrotolublye was met with a positive reaction in Russian intellectual circles, which were then looking for a deeper meaning of life. Predictably, the first print run sold out a few months later. In 1798, the second part of Dobrotolublye was released. The collection was then reprinted by the Metropolitan of Moscow, Filaret (Drozdov) in 1822. Further editions followed in 1832, 1840, 1851, 1857, 1880 and 1902; a partial translation of Dobrotolublye was released by Teophan Zatvornik in 1877 . This collection greatly contributed to the spread of hesychastic tradition in Russia and the philokalic spirit reached as far as Alaska, when Russian empress Catherine II. asked the Metropolitan Gabriel to send missionaries there. Metropolitan turned to hegumen Nazariy with a plea to prepare monks from Valaam for this mission. Among these was also the venerable Herman of Alaska (1756-1837), an important figure in North American orthodoxy. A small island near Kodiak, then called New Valaam, became the center of education for Alaskan Aleuts.

Nazariy Kondratyev elevated the Valaam monastery both materially and spiritually ${ }^{4}$ and helped to transpose the spiritual experience of the niptic fathers into Russian monastic practice, a fact that was instrumental for the development of hesychastic tradition and spiritual renewal of the Russian society. As Georges Florovsky states, "the publishing of Slavic-Russian Dobrotolublye is a milestone not only for the history of Russian monasticism, but also for the general history of Russian culture" (Florovsky 2006, p. 128). In 1801, thirty-eight experienced disciples of Paisius Velichkovsky came to Russia and became the teachers of the hesychastic tradition, which was to greatly impact Russian culture. In October 1805, starets Nazariy resigned from his office of hegumen of Valaam monastery and returned to Sarov hermitage.

\subsection{Staretsdom as a Part of the Russian Spiritual Tradition}

The influence of Greek spirituality on Russian culture manifested most prominently in the activities of startsy of Optina hermitage, which became the focal point of hesychastic tradition in Russia. After the arrival of the disciples of Paisius Velichkovsky, it experienced unprecedented growth and soon became famous throughout Russia. One of the most prominent figures of the monastery was Moses Putilov (1782-1862), who got acquainted in his youth with startsy Alexander and Filaret, who were spiritually close to Paisius Velichkovsky. Under their guidance, he decided to become a monk and, in 1804, left for Sarov hermitage, which was blooming at that time thanks to the great ascetics, applying the experiences of Greek niptic fathers to practice. During his stay at Sarov, he learned of hesychastic tradition and spiritual struggles of Seraphim of Sarov and Nazariy Kondratyev, both discussed earlier.

In 1811, Moses consigned himself to the spiritual guidance of starets Athanasius, a disciple of Paisius Velichkovsky, and lived as a hermit in the forests of Roslavl. During his years as a hermit, he matured spiritually, attained a deep knowledge of niptic texts and grew into remarkable concentration, reticence and watchfulness of mind. His diary entries from this period are a testament to an impressive spiritual refinement.

Kalugan bishop Filaret, later the Metropolitan of Kiev, wanting to support the hesychastic tradition then gradually extending across Russia, suggested to Moses in 1821 to come to Optina hermitage and fund a skete approximately five hundred meters away from 
the monastery. This way, he wanted to provide the monks with space for ascetic quietude and constant prayer. Moses accepted the proposal and departed for Optina, together with his brother Antoniy and two other Roslavl hermits.

Moses was ordained and nominated to the clergy of Optina monastery. Three years later, he was selected to be the archimandrite of the monastery, which he took care of for thirty-seven years. Optina changed extensively under his supervision; the number of monks grew manifold, the spiritual climate of the monastery improved significantly.

Droves of people came to Optina; father Moses welcomed each of them gladly, discussing a plethora of spiritual topics with them. He devoted himself to the service of his kin and he was able to understand and spiritually bolster each of them. He was known to be affable in all duties and malice had no place in his heart. It is reported that whenever he felt anger towards a monk, he immediately left to seek humility through prayer and only then returned. Though he was short-tempered by nature, he achieved remarkable humility through a strict ascetic life. He accepted the failures of his monks calmly and with fatherly love. He never used harsh measures and claimed that it is necessary to wait until God touches the heart of man. He tried to understand the character and the level of the spiritual life of each individual person.

Father Moses' greatest import was the bolstering of staretsdom in Optina monastery, primarily by receiving two experienced startsy Leonid and Macarius. Though he himself had a gift of staretsdom, he hid it from others, knowing that the monks can have only a single spiritual guide, thus shying away from guiding the monks for the entirety of his life. Despite remaining the archimandrite of the monastery, he fully devoted himself to obedience of these two startsy and considered his supervising the monastery to be an act of obedience. Thus, a principle came into force that the hegumen is a supervisor of a monastery, taking care of its functioning, but the spiritual life of monks is attended by a spiritual leader-starets, who accepts the responsibility for their souls before God. Spiritual guidance-staretsdom leads people to the authentic way of life. The rules of staretsdom, which gradually became an inseparable part of Russian spiritual tradition, were supported also by bishop Filaret.

The disciples of Paisius Velichkovsky initiated Moses, Leonid, and Macarius into the hesychastic way of life and let them to the constant prayer of the mind. They expounded to them the time-proven ascetic practice and acquainted them with Byzantine niptic texts translated by Paisius Velichkovsky. All three Optina startsy valued his translations greatly, collecting them in the skete's library, which eventually contained the entire body of both his translations and his own writing. Starets Moses brought with him from Kaluga the texts of niptic authors and, after reading, submitted them to the monastery's library, which attained prestige already during his lifetime. Starets Leonid got hold of the manuscript translations of niptic texts via Paisius' disciple, starets Feodor. Starets Macarius, too, held manuscript translations in his library, produced by Paisius' disciple Athanasius.

\section{Macarius' Publishing Activities}

Starets Macarius was aware that people's indifference towards faith resulted from a misunderstanding of the essence of Christianity and decided to publish niptic texts of Byzantine authors, which were translated by Paisius Velichkovsky. These texts had not been published in full and were practically inaccessible to Russian readers. He strove to strengthen the faith of Christians and lead them to an authentic life through well-made spiritual literature, thus making the publishing of these texts his primary goal. He was helped the most by his spiritual children, especially the Kireyevskys.

Ivan Vasilyevich Kireyevsky (1806-1856), one of the co-founders of the Slavophile alongside Aleksey Stepanovich Khomyakov, was a famous Russian philosopher, author and literary critic (Zenkovskij 1948, pp. 215-35; Christoff 1991). He studied in Germany under the philosopher F. W. Schelling and theologian F. Schleiermacher, whose ideas did not satisfy his metaphysical pursuits. Upon returning to Russia, he started to look for new philosophical directions. A turning point in his life and thought came with his marriage 
to Natalia Petrovna Arbeneva (Tachiaos 2006, p. 229), who was a friend of starets Filaret, introducing him to her husband. Starets Filaret used to speak of the life and deeds of Paisius Velichkovsky and gifted several manuscripts of his translations of niptic authors to Natalia.

The Kireyevskys lived in Moscow and had an estate in Dolbino, a village near the Optina hermitage. In the 1840s, they became acquainted with the startsy of the Optina hermitage, notably with starets Macarius, who became their spiritual father. Starets Macarius frequently visited Kireyevskys' estate, sometimes staying over for several days. A sincere friendship developed between them, and the couple showed him great love and respect. They often talked about starets Paisius Velichkovsky and his literary works, greatly admired by the Kireyevskys.

Ivan Kireyevsky was enthralled by the spiritual and intellectual wealth of Greek niptic texts, which he had not known until then. He believed that the fathers' thought, terminology and logical argumentation could supplement the lacking aspects of contemporary philosophy. Despite the philokalic spirit being contradictory to Western philosophical movements, this contrast was not an ideological attack; Kireyevsky thus neither denied nor rejected philosophy, but rather sought to enrich it with new elements on the basis of the ascetic and hesychastic experience of niptic authors (Kireyevsky 1911, pp. 223-64; Kireyevsky 1979, pp. 314-55). Ivan Kireyevsky was one of the first representatives of Russian culture to initiate the "breakthrough in Russian thinking" (Gercen 1958, pp. 169-70).

He became a devout spiritual son of starets Macarius (Chetverikov 1988, pp. 119-202) and in all his philosophical writings sought a way out of the spiritual crisis, into which Russian society fell under the influence of the Enlightenment. In 1845, Kireyevsky suggested starets Macarius write an article with spiritual contents for the magazine The Muscovite (Москвитянин [Moskvitjanin]) that he was editing at that time. Macarius agreed to this and decided to publish a biography of the starets Paisius Velichkovsky in the form of an article, which saw print in the 12th issue of the magazine, in 1845.

Starets Macarius visited the Kireyevskys' estate the next year and raised the question of an insufficient number of spiritual books available in Russian. He mentioned that there was a great number of manuscript translations of Byzantine niptic texts in the library at Optina Skete. Natalia Petrovna informed him that she also had several such manuscripts at her disposal. Gradually, the idea to publish these rare texts-unknown to ordinary Christians interested in spiritual life and monks alike-was born. However, the humble starets warned them that he did not consider himself suited for publishing niptic texts. The Kireyevskys assured him that they will take care of it and would inform Filaret, the Metropolitan of Moscow, and ask him for his blessing. Through their acquaintances, they approached the Metropolitan, who gave them his blessing for this task, much pleased with their altruism. He even promised to help and support them.

Publishing of Russian translations of niptic texts thus started at Optina under the patronage of the Metropolitan of Moscow. The process was overseen by starets Macarius himself, who devoted much time and effort to this activity. Transcripts of individual manuscripts were delivered to Moscow Theological Academy for censorship. During the editing of these texts, consultations with the Metropolitan Filaret took place frequently, as he cared deeply for the accuracy of the published works.

In January 1847, the first book of Optina edition was published under the title Life and Writings of the Moldavian Starets Paisius Velichkovsky. Starets Macarius wrote a preface to the biography, which was conceived by Paisius' students, added a selection of his works, letters and a few texts by the starets Basil of Poiana Mărului who was a friend to Paisius Velichkovsky. This book quickly sold out and issuing of a second edition was soon agreed on.

Starets Macarius led a group of intellectuals and writers from the ranks of both monks and laypeople, who processed and published the writings of the most significant niptic authors based on Paisius' translations into the literary Russian language. The publishing of Byzantine niptic texts in Russian was of great importance for the development of Russian 
monasticism, yet it also significantly shaped the Russian terminology and influenced Russian literature and culture.

At Metropolitan Filaret's invitation in 1852, starets Macarius visited Moscow and the Trinity Lavra of St. Sergius, where he met professor Fyodor Alexandrovich Golubinsky from the Moscow Theological Academy, responsible for censorship of the published texts. Professors from the Imperial Moscow University-Stepan Petrovich Shevyryov, Mikhail Petrovich Pogodin, and others-also participated in the publishing process. Contacts between the Optina hermitage and intellectual circles in Moscow began to strengthen. Furthermore, starets Macarius' influence on monks from various Russian monasteries intensified and his spiritual experience was reflected in leading and development of many female monasteries as well.

Publishing activity of starets Macarius persisted despite the death of Ivan Kireyevsky in 1856. However, he was not able to conduct such demanding and extensive work all by himself. Therefore, there arose a group of collaborators, in a manner similar to collaborators of starets Paisius Velichkovsky. These included primarily his disciples at the Skete: father Ambrose Grenkov (who later became a famous starets and successor to father Macarius), father Leonid Kavelin (who later became the archimandrite of the Trinity Lavra of St. Sergius), father Clement Zedergolm (magister of classic philology at Imperial Moscow University), father Yuvenaliy Polovtsev (who later became Lithuanian archbishop), and others.

Under the guidance of starets Macarius, his collaborators worked with the manuscripts daily and tried to accurately capture, or at least explain, the ideational and expressive nuances of the niptic texts. Translation of the Greek texts led to development of terminology in the Russian language, which had to correspond to the original meanings of ascetic struggle and degrees of spiritual self-improvement. It was a highly valuable experience for starets Macarius' disciples, since they studied thoughts and statements of niptic authors and strove to comprehend the meaning of their advice, which they applied to practical life under the guidance of the starets. At the same time, they had the opportunity to continually listen to starets' explanations of the most important questions related to monastic life, constant prayer, and spiritual struggle. For Macarius, it was a markedly time-consuming period, as he was directly involved in the publishing and had to carefully check each manuscript before sending it for censorship in addition to receiving the monks and pilgrims he led spiritually. He was well aware that it is essential to appropriately translate each word pertaining to the definition of human spiritual life.

After his death, Natalia Kireyevskaya managed to publish the starets' letters addressed to monks in four volumes and letters addressed to laypeople in one volume. These letters contained rare examples of Christian life based on works of niptic fathers and their very own spiritual experience, sensitivity and extraordinariness of humble and loving heart, explaining a multitude of topics with incredible simplicity.

\section{Conclusions}

The analysis carried out shows that the philokalic spirit, which transposed the Greek hesychastic tradition into Russian cultural context by translations of Byzantine niptic texts produced by Paisius Velichkovsky and his disciples, significantly influenced not only Russian spirituality, but its culture on a grander scale. The centers of Hesychasm in Sarov, Valaam and Optina provided a new prism through which to view spiritual life and left a notable mark on Russian society. The greatest import of the Optina monastery lies in publishing activities, as a multitude of texts introducing the immeasurable wealth of niptic thought to the general public was published there. Starets Macarius spent fifteen years producing translations of niptic works and, under his supervision, an entire school of translators and publishers of spiritual and ascetic literature emerged. The idea of translation and publishing of these texts, then unknown to the majority of educated Russians, caught the attention of both intellectual circles and simple folk, pointing them to Optina, which thus significantly contributed to the contemporary shape of the Russian 
society. Using a modern philosophical language, Ivan Kireyevsky popularized the ideas of Greek niptic authors and laid the foundations of a new philosophy, which greatly contributed to the spiritual renewal of Russian society and led to a remarkable flourishing of Russian spirituality, culture and literature. At the same time, cooperation between Optina startsy and Russian intellectuals started to take form. This can also be seen in the fact that startsy received visits from such prominent figures of Russian society as Nikolai Vasilyevich Gogol, Konstantin Nikolayevich Leontiev, Fyodor Mikhailovich Dostoevsky, Lev Nikolayevich Tolstoy, Vladimir Sergeyevich Solovyov. These great minds and many others, disgusted by the spiritual crisis, came to Optina and, in discussions with the wise startsy, found spiritual values which had previously disappeared from social awareness as a side effect of Enlightenment. Under the influence of startsy, their worldview changed, leading also to a change in their artistic work.

Funding: This work was supported by the Slovak Research and Development Agency under the contract No. APVV-16-0116.

Data Availability Statement: Data sharing not applicable.

Conflicts of Interest: The author declares no conflict of interest.

\section{Notes}

Typikon is the internal order of a monastery.

2 The name Kyiv Pechersk Lavra is derived from the root пещера [peshhera], meaning cave. In the beginning, it was a cave complex where the monks dwelt. Today, these caves are connected into long, narrow tunnels.

3 In Russian monastic terminology, the word starets (старец-lit. elder, pl. startsy) means spiritual leader. It was used to describe great monastic figures, who significantly influenced spiritual life in Russia in the 18th century.

4 The last hegumen of the Valaam monastery was father Chariton (Dunayev), who held office until 1983, and furthered the line of starets Nazariy, publishing the collection On Jesus Prayer (О молитве Иисусовой [O molitve Iisusovoj]). It contained the lectures of great ascetics on prayer and his contemporaries called it Small Dobrotolublye.

\section{References}

Chetverikov, Sergey. 1988. Оптина Пустынг [Optina Pustyn] (Opta's Hermitage), 2nd ed. Paris: YMCA-PRESS.

Christoff, Peter. 1991. An Introduction to Nineteenth-Century Russian Slavophilism. New York: Routledge.

Deseille, Placide. 1997. La Spiritualité Orthodoxe et la Philocalie (Orthodox Spirituality and Philocaly). Paris: Bayard Éditions.

Florovsky, Georges. 2006. Пути русского богословия [Puti russkogo bogosloviya] (The Paths of Russian Theology). Харвест: Издательство Белорусского Экзархата.

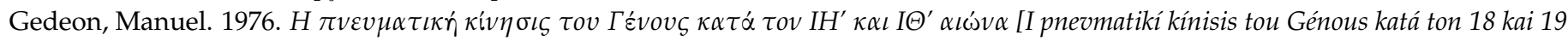

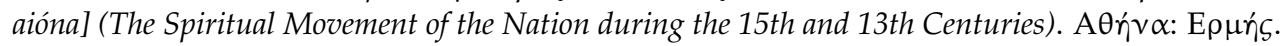

Gercen, Alexander Ivanovich. 1958. Былое и думы (The past and thoughts). In Собрание сочинений в тридиати томах (Collected Works in Thirty Volumes). Москва: Академия наук СССР. Том девятый, pp. 133-71.

Joanta, Romul. 1987. Roumanie: Tradition et Culture Hésychastes (Romania: Hesychast Tradition and Culture). Bégrolles-en-Mauges: Abbaye de Bellefontaine.

Karamanidou, Anna. 2016. European Enlightenment and Orthodox Christian Illumination. The Potential Survival of Hesychasm in the Movement of Kollyvades. Constantine's Letters 1: 158-82. [CrossRef]

Kireyevsky, Ivan. 1911. О необходимости и возможности новых начал для философии [O neobkhodimosti i vozmozhnosti novykh nachal dlya filosofii] (On the necessity and possibility of new beginnings for Philosophy). In Полное собрание сочинений, Volume 1 (Complete Works, Volume 1). Москва: Типографія Императорскаго Московскаго Университета.

Kireyevsky, Ivan. 1979. Критика и эстетика [Kritika i estetika] (Criticism and Aesthetics). Москва: Искусство.

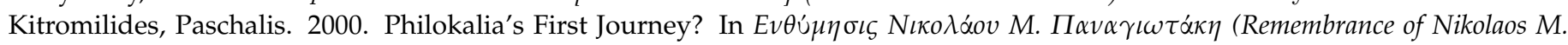
Panagiotakis). Irakleio: Crete University Press, pp. 341-60.

Koncevitch, E. 1981. Преп. Серафимг Саровскій Чудотворецъ [Prep. Serafim Sarovskiy Chudotvorets] (Saint Seraphim of Sarov). California: Свято-Ильинское издание, Available online: https://elibrary.domrz.ru/absopac/app/webroot/index.php?url= /notices/index/IdNotice:13160/Source:default (accessed on 21 June 2021).

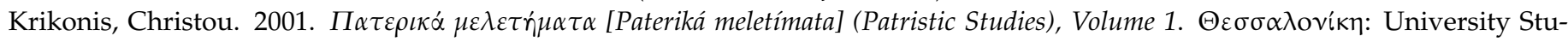
dio Press.

Lamprou, Soultana. 2017. The Classical Education of St. Gregory Palamas through Indicative Examples. Constantine's Letters 2: 126-32. [CrossRef] 
Lemerle, Paul, ed. 1970. Actes de Lavra. Part 1. Des origines à 1204. (Archives de l'Athos, Number 5) [Acts of Lavra. Part 1. From the origins to 1204. (Athos Archives, Number 5)]. Paris: Éditions P. Lethielleux, $\mathrm{N}^{\mathrm{O}} 19$.

Milko, Pavel. 2016. Selected Questions of Byzantine Philosophy. Constantine's Letters 1: 119-35.

Minin, N. A. 2011. Преподобный Назарий, игумен Валаамский.Жизнеописание. Духовные наставления /Prеродоbnуy Nazariy, igumen Valaamskiy. Zhizneopisaniye. Dukhovnyye nastavleniyal (Saint Nazarius, Abbot of Valaam. Biography. Spiritual Instruction). Валаам: Спасо-Преображенский Валаамский монастырь.

Olshevskaya, Lidiya Alfonsovna, and Sergey Nikolayevich Travnikov. 1999. Древнерусские патерики: Киево-Печерский патерик. Волоколамский патерик [Drevnerusskiye pateriki: Kiyevo-Pecherskiy paterik. Volokolamskiy paterik] (Old Russian Patericons: Kiev-Pechersk Patericon. Volokolamsk Patericon). Москва: Наука.

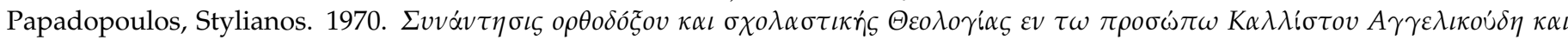

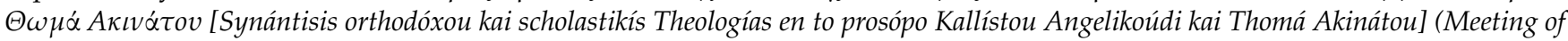
Orthodox and Scholastic Theology in the Person of Kallistos Angelikoudis and Thomas Aquinas). Thessaloniki: П $\alpha \tau \rho\llcorner\alpha \rho \chi\llcorner\kappa o ́ ~ ' I \delta \rho v \mu \alpha$ $\Pi \alpha \tau \varepsilon \rho \iota \kappa \omega ́ v ~ M \varepsilon \lambda \varepsilon \tau \omega \dot{\omega} v$.

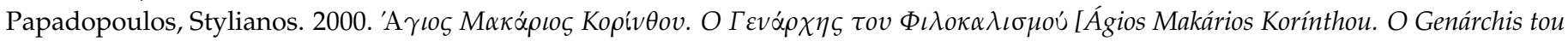

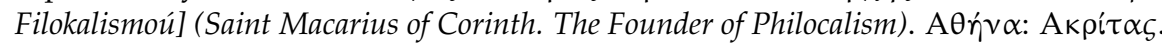

Pavlikianov, Cyril. 2018. Medieval Slavic Acts from Mount Athos 1230-1734. Sofia: "St. Kliment Ohridski" University Press.

Poppe, Andzej. 2011. Студиты на Руси: Истоки и начальная история Киево-Печерского монастыря [Studity na Rusi: Istoki $i$ nachal'naya istoriya Kiyevo-Pecherskogo monastyryal (Studites in Russia: The Origins and Initial History of the Kiev-Pechersk Monastery). Kyiv: Ruthenica.

Priselkov, M. D. 1913. Ocherki po Tserkovno-Politicheskoi Istorii Kievskoi Rusi X-XII vv (Essays on the Church-Political History of Kievan Rus in X-XII Centuries). St. Petersburg: Tip. M. M. Stasiulevicha.

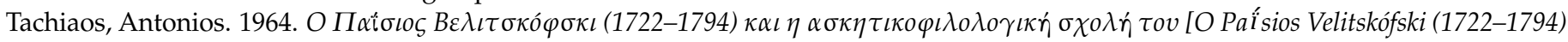

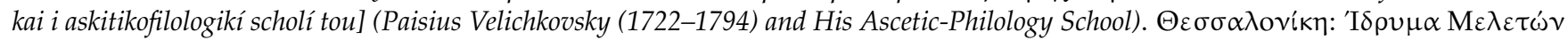

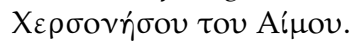

Tachiaos, Antonios. 1978. Mount Athos and the Slavic Literatures. Cyrillomethodianum IV: 1-35.

Tachiaos, Antonios. 1986. The Revival of Byzantine Mysticism among Slavs and Romanians in the XVIIIth Century. Texts Relating to the Life

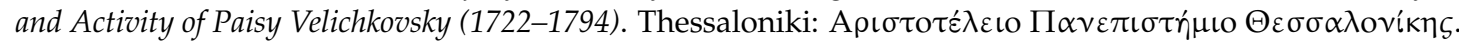

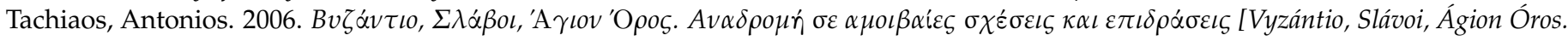
Anadromí se amoivaies schéseis kai epidráseis] (Byzantium, Slavs, Mount Athos. The Retrospection of Mutual Relationships and Influences). $\Theta \varepsilon \sigma \sigma \alpha \lambda$ ovín: UNIVERSITY STUDIO PRESS.

Thomson, Francis J. 1995. Saint Anthony of Kiev-The Facts and the Fiction. The Legend of the Blessing of Athos upon Early Russian Monasticism. Byzantinoslavica 56: 637-68.

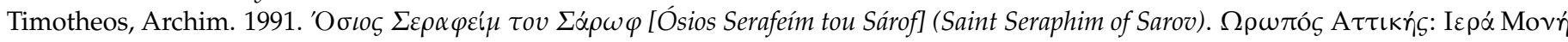
$\Pi \alpha \rho \alpha \kappa \lambda \dot{\tau} \tau$ ov.

Uspenskij, Boris A. 2016. St. Anthony of Kiev and the Earliest History of Russian Monasticism (Novitiates in Old Rus'). Slověne. International Journal of Slavic Studies 5: 70-113. [CrossRef]

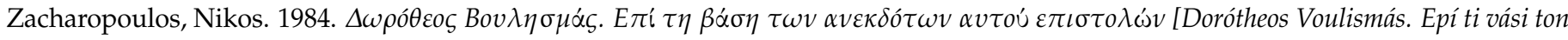
anekdóton aftoú epistolón] (Dorotheos Voulismas. On the Basis of His Unpublished Letters). Thessaloniki, Unpublished Manuscript.

Zenkovskij, Vasilij. 1948. История русской философии [Istoriya russkoy filosofii] (History of Russian Philosophy). Париж: YMCA-PRESS, vol. 1.

Zozul'aková, Viera. 2016. Practical Philosophy in the Lives of Constantine and Methodius. Constantine's Letters 1: 149-57. [CrossRef]

Župina, Miroslav. 2017. Mystical Realism of Gnoseology of Symeon the New Theologian. Constantine's Letters 1: 73-82.

Zhitiye, I pisaniya. 1847. Житие и писания молдавского стариа Паисия Bеличковского [Zhitiye i pisaniya moldavskogo startsa Paisiya Velichkovskogol (The Life and Writings of the Moldavian Elder Paisius Velichkovsky). Москва: Издание Козельской Введенской Оптиной пустыни. 